\title{
The Cytocompatibility and Early Osteogenic Characteristics of an Injectable Calcium Phosphate Cement
}

DENNIS P. LINK, M.Sc., JULIETTE VAN DEN DOLDER, Ph.D., JOOP G.C. WOLKE, Ph.D., and JOHN A. JANSEN, D.D.S., Ph.D.

\begin{abstract}
In this study, the cytocompatibility and early osteogenic characteristics of rat bone marrow cells (RBMCs) on injectable calcium phosphate $(\mathrm{CaP})$ cement (Calcibon) were investigated. In addition to unmodified CaP cement discs, 2 other treatments were given to the discs: preincubation in MilliQ and sintering at different temperatures. After primary culture, RBMCs were dropwise seeded on the discs and cultured for 12 days. The samples were evaluated in terms of cell viability, morphology (live and dead assays and scanning electron microscopy (SEM)), cell proliferation (deoxyribonucleic acid (DNA) analyses), early cell differentiation (alkaline phosphatase (ALP) activity), and physicochemical analyses ( $x$ ray diffraction (XRD)). The live and dead, DNA, and SEM results showed that Calcibon discs without any additional treatment were not supporting osteoblast-like cells in vitro. There were fewer cells, and cell layers were detached from the disc surface. Therefore, different preincubation periods and sintering temperatures were evaluated to improve the cytocompatibility of the CaP cement. Preincubating discs in MilliQ for periods of $1,4,8$, and 12 weeks resulted in the hydrolysis of $\alpha$-tri calcium phosphate (TCP) into an apatite-like structure with some $\beta$-TCP, as shown with XRD, but the material was not cytocompatible. Sintering the discs between $800^{\circ} \mathrm{C}$ and $1100^{\circ} \mathrm{C}$ resulted in conversion of $\alpha$-TCP to $\beta$-TCP with some hydroxyapatite and an increase in crystallinity. Eventually, the discs sintered at $1100^{\circ} \mathrm{C}$ achieved better cell attachment, more-abundant cell proliferation, and earlier differentiation than other sintered $\left(600^{\circ} \mathrm{C}, 800^{\circ} \mathrm{C}\right.$, and $\left.1000^{\circ} \mathrm{C}\right)$, preincubated, and unmodified specimens. On basis of our results, we conclude that in vivo results with CaP-based cements do not guarantee in vitro applicability. Furthermore, unmodified Calcibon is not cytocompatible in vitro, although preincubation of the material results in a more-favorable cell response, sintering of the material at $1100^{\circ} \mathrm{C}$ results in the best osteogenic properties. In contrast to in vivo studies, the Calcibon CaP cement is not suitable as a scaffold for cellbased tissue-engineering strategies.
\end{abstract}

\section{INTRODUCTION}

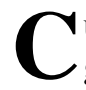

URRENTLY, THE USE OF autologous and allogenous bone grafts is the method of choice for the treatment of large bone defects caused by trauma, disease, or tumor resection. However, both of these methods are associated with significant clinical problems such as donor site morbidity and the possible transfer of disease. In view of this, innovative bone- engineering techniques have been introduced that include the use of a suitable scaffold in combination with mesenchymal stem cells. ${ }^{1-8}$ Although the achieved results hold promise, the final goal (the safe and reliable healing of large bone defects) has not been accomplished. Current drawbacks of cell-based bone engineering are the low yield of cells with bone inducing capacities and the lack of standardized expansion and differentiation of progenitor cells.

Radboud University Nijmegen Medical Center, Department of Periodontology and Biomaterials, Nijmegen, The Netherlands. 
As a consequence, reproducibility and predictability in human patients is low. Several solutions have already been suggested to solve this problem, such as the use of cell selection, ${ }^{9-11}$ dynamic cell culture (flow perfusion system), ${ }^{12-16}$ and encapsulation of cells in microspheres. ${ }^{17-20}$ The final cell population has to be incorporated in a scaffold material that possesses intrinsic osteophilic properties. For bone purposes, the ideal scaffold material is considered to be bioactive, slowly biodegradable, moldable, and easy to apply. The scaffold material must also have a certain porosity, and the pores must have interconnectivity to allow tissue ingrowth and stabilization. The recently developed calcium phosphate $(\mathrm{CaP})$ cements appear to fulfill these requirements, because they support bone growth (osteoconductive), are degradable because of osteoclastic remodeling, are injectable, can incorporate microspheres, and can be made micro- and macroporous to allow penetration of nutrients and clearance of waste. ${ }^{21-27}$ Unfortunately, the results obtained with the culturing of osteoblastic cells on $\mathrm{CaP}$ cements are contradictory. This can be due to the composition of the starting powder used for the preparation of the $\mathrm{CaP}$ cement. For example, different $\mathrm{CaP}$ mixtures have been used, such as tetra calcium phosphate, dicalcium phosphate dehydrate, calcium pyrophosphate, tri calcium phosphate (TCP), which transform into materials composed of hydroxyapatite, carbonated apatite, and amorphous $\mathrm{CaP}$ during setting. However, calcium and phosphate ions can be released during this transformation process, which can be harmful during cell culturing. The size or geometry of the cement samples, manufacturing conditions, cell media changes, and total cell-medium volume, among other things, can enhance this effect. Evidently, no problems have been observed for the in vivo behavior of these $\mathrm{CaP}$ cement materials because the toxic products are sufficiently transported away during the initial phases of wound healing. At the same time, this phenomenon can explain the contradictory cell culture studies. For example, using the $\mathrm{CaP}$ cement Calcibon (Merck Biomaterial GmbH, Darmstadt, Germany), Hempel et al. found a lower cell proliferation and differentiation than with polystyrene cultures. The CaP scaffolds in this study were preincubated in simulated body fluid for 4 days. $^{28}$ In contrast to Hempel et al., Oreffo et al. and Knabe et al. reported lower cell proliferation and greater cell differentiation on this material than with polystyrene cultures. Oreffo et al. preincubated the $\mathrm{CaP}$ scaffolds for 5 days in Ringer's solution, and Knabe et al. sterilized the scaffolds at $300^{\circ} \mathrm{C}$ for $3 \mathrm{~h}^{28-30}$

Consequently, before the final use of $\mathrm{CaP}$ cement as scaffold material for a cell-based tissue-engineering approach, the cyto-compatibility of such a material has to be determined. In the current study, unmodified discs, together with discs preincubated in MilliQ and discs sintered at different temperatures, were used. These additional treatments can create phase transformations of the $\mathrm{CaP}$ cement, which can affect the cellular response.

\section{MATERIALS AND METHODS}

\section{Substrates}

Calcibon was used. The chemical composition of this cement is $62.5 \% \alpha$-TCP, $26.8 \%$ dicalcium phosphate dihydrate, $8.9 \%$ calcium carbonate, and $1.8 \%$ precipitated hydroxyapatite. An aqueous solution of $1 \%$ disodium hydrogen phosphate dodecahydrate is used as the liquid component. The ideal liquid-to-powder ratio for clinical applications has been shown to be $0.35 \mathrm{~mL} / \mathrm{g}$. After mixing, the cement was immediately injected into a circular-shaped mould to ensure a standardized shape of the discs (cylinders of about $2.4 \mathrm{~mm}$ height and $6 \mathrm{~mm}$ diameter). The discs were removed from the molds after the cement had set. Histo-morphometrical analysis revealed that the total microporosity (pores $<1 \mu \mathrm{m}$ ) of the cement was approximately $30 \%$ to $40 \%$. In addition to the unmodified CaP cement discs, samples were preincubated $(1,4,8$, and 12 weeks) on a rotating plate in MilliQ, which was refreshed 3 times a week or sintered in a furnace for $2 \mathrm{~h}$ at $600^{\circ} \mathrm{C}, 800^{\circ} \mathrm{C}$, $1000^{\circ} \mathrm{C}$, or $1100^{\circ} \mathrm{C}$.

The chemical composition of the samples was evaluated crushing the samples with a mortar until the discs were reduced to powder and then analyzing them using $\mathrm{X}$-ray diffraction (XRD, Philips PW3710, Eindhoven, The Netherlands). The positions and intensities of the XRD peaks were used to identify the underlying structure (or phase) of the various treatments of the specimens.

\section{Cell isolation}

Rat bone marrow cells (RBMCs) were isolated and cultured using the method described by Maniatopoulos. ${ }^{31}$ RBMCs were obtained from femora of male Wistar rats weighing between $120 \mathrm{~g}$ and $150 \mathrm{~g}$. Femora were washed 3 times in culture medium minimal essential medium (MEM) (Gibco BRL, Life Technologies B.V., Breda, The Netherlands) with $0.5 \mathrm{mg} / \mathrm{mL}$ gentamycin and $3 \mu \mathrm{g} / \mathrm{mL}$ Fungizone. Epiphyses were cut off and diaphyses flushed out with $15 \mathrm{~mL}$ complete culture medium $\alpha$-MEM supplemented with $10 \%$ fetal calf serum (Gibco), $50 \mu \mathrm{g} / \mathrm{mL}$ ascorbic acid (Sigma Chemical Co., St. Louis, MO), $50 \mu \mathrm{g} / \mathrm{mL}$ gentamycin, $10 \mathrm{mM}$ sodium $\beta$-glycerophosphate (Sigma), and $10^{-8} \mathrm{M}$ dexamethasone (Sigma). Cells were incubated in a humidified atmosphere of $95 \%$ air, $5 \%$ carbon dioxide at $37^{\circ} \mathrm{C}$. The medium was changed 3 times a week.

After 7 days of primary culture, cells were detached using trypsin/ethylenediaminetetraacetic acid (EDTA) $(0.25 \% \mathrm{w} / \mathrm{v}$ trypsin/0.02\% EDTA). The cells were concentrated using centrifugation at $1500 \mathrm{rpm}$ for $5 \mathrm{~min}$ and resuspended in a known amount of medium. Cells were counted using a Coulter counter (Beckman Coulter, Mijdrecht, The Netherlands) and resuspended in complete culture medium. A cell suspension of 50,000 cells per disc was used for the seeding and culturing experiments. 


\section{Cell viability}

Live and dead viability assays (Molecular Probes, Leiden, The Netherlands) ( $n=2$ for all culture periods), consisting of washing with phosphate buffered saline (PBS), covering with a mix of calcein AM $(1.0 \mu \mathrm{l})$ and ethidium homodimer $(3.5 \mu \mathrm{l})$, incubating 30 to $45 \mathrm{~min}$ at $37^{\circ} \mathrm{C}$, washing with PBS, and examining under a fluorescence microscope, were performed on days $0,1,2,4,8$, and 12 ,. Metabolically active cells were converting the calcein AM into green fluorescent calcein through intracellular esterases, where ethidium homodimer entered dead cells through damaged membranes to bind deoxyribonucleic acid (DNA). Green cells were viable, and red cells were considered to be dead.

\section{DNA analyses}

DNA assays (Molecular Probes) ( $n=6$ for all culture periods) were performed on days $0,1,2,4,8$, and 12 . Culture medium was removed, and discs were washed twice with PBS. One $\mathrm{mL}$ of MilliQ was added to each sample. Cells were harvested by placing the discs with inoculated cells in a 1.5-mL tube. One $\mathrm{mL}$ of MilliQ was added to each sample. Cell suspension was frozen to $-80^{\circ} \mathrm{C}$, heated to $37^{\circ} \mathrm{C}$, frozen to $-80^{\circ} \mathrm{C}$ again, and stored at $-80^{\circ} \mathrm{C}$ until usage.

A DNA standard curve was made using salmon testes DNA. One hundred $\mu \mathrm{l}$ of sample or standard were added to $100 \mu \mathrm{l}$ of Pico green working solution. The samples were incubated for $5 \mathrm{~min}$ at room temperature in the dark. After incubation, DNA was measured using a fluorescence microplate reader (Bio-Tek Instruments, Abcoude, The Netherlands) with excitation filter $365 \mathrm{~nm}$ and emission filter $450 \mathrm{~nm}$.

\section{ALP activity}

For the ALP assay (Sigma), the same samples from the DNA assay were used. Eighty $\mu$ l of sample and $20 \mu$ of buffer solution (5 mM magnesium chloride, $0.5 \mathrm{M} 2$-amino-2methyl1-propanol) were added in a 96-well plate. One hundred $\mu \mathrm{l}$ of substrate solution ( $5 \mathrm{mM}$ p-nitrophenylphosphate) was added to the well, and the plate was incubated for $1 \mathrm{~h}$ at $37^{\circ} \mathrm{C}$. The reaction was stopped by adding $100 \mu \mathrm{l}$ of stop solution $(0.3 \mathrm{M}$ sodium hydroxide). For the standard curve, serial dilutions of 4-nitrophenol were added to final concentrations of 0 to $25 \mathrm{nM}$. The plate was read in an enzyme-linked immunosorbent assay reader (Bio-Tek Instruments) at $405 \mathrm{~nm}$. ALP activity results were normalized to ng of DNA.

\section{Scanning electron microscopy}

SEM analyses $(n=2$ for all culture periods) were performed on days $0,1,2,4,8$, and 12 . The samples were washed twice with PBS. Fixation was carried out for $10 \mathrm{~min}$ in $2 \%$ glutaraldehyde, and then substrates were washed twice with $0.1 \mathrm{M}$ sodium-cacodylate buffer ( $\mathrm{pH} 7.4$ ), dehydrated in a graded series of ethanol, and dried using tet- ramethyl silane. The specimens were sputter-coated with gold and examined and photographed using a Jeol 6310 SEM at an acceleration voltage of $10 \mathrm{kV}$. SEM was performed at the Microscopic Imaging Center of the Nijmegen Center for Molecular Life Sciences, The Netherlands.

\section{Statistical analyses}

Statistical analyses were performed using GraphPad Instat 3.05 software (GraphPad Software Inc., San Diego, CA) using one-way analyses of variance with a Tukey multiple comparison post test.

\section{RESULTS}

\section{Unmodified Calcibon}

The results of the XRD analyses (Fig. 1) demonstrated that the unmodified $\mathrm{CaP}$ cement discs were mainly composed of $\alpha$-TCP. These samples caused the $\mathrm{pH}$ of the culture
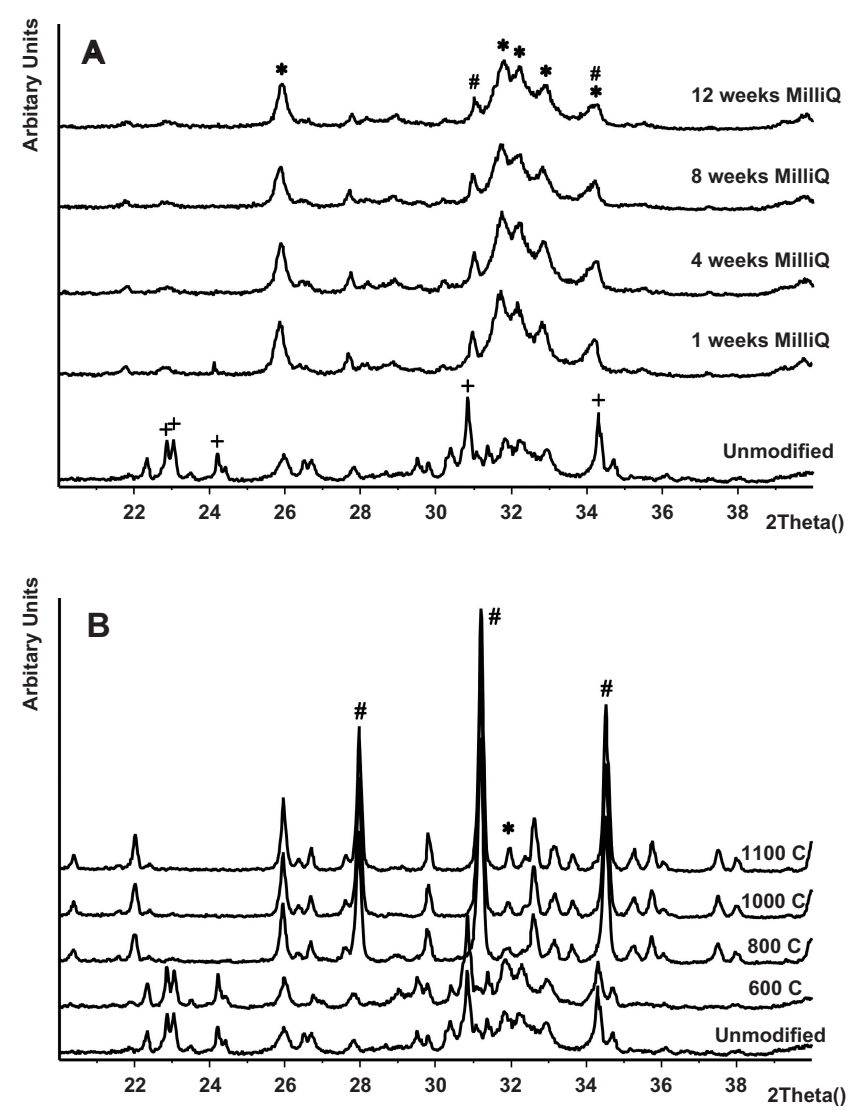

FIG. 1. X-ray diffraction (XRD) analyses of the calcium phosphate cement discs. The XRD powder patterns of (A) unmodified and discs preincubated for $1,4,8$, and 12 weeks and (B) unmodified discs and discs sintered at $600^{\circ} \mathrm{C}, 800^{\circ} \mathrm{C}, 1000^{\circ} \mathrm{C}$, and $1100^{\circ} \mathrm{C}$ are shown, respectively. $(*=$ apatite; $\#=\beta$-tri calcium phosphate (TCP); $+=\alpha$-TCP). 

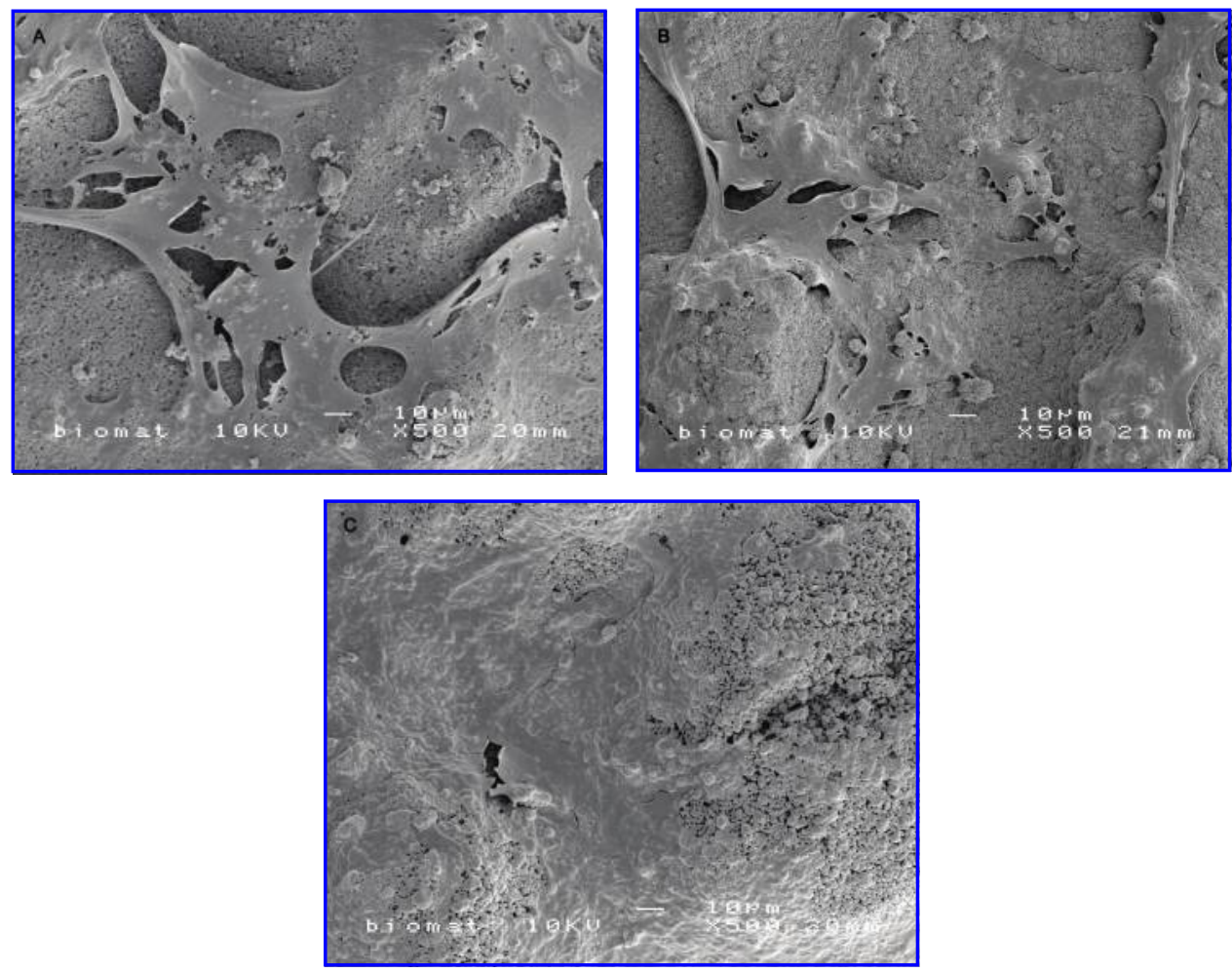

FIG. 2. Scanning electron microscopy of (A) unmodified discs, (B) discs preincubated for 1 week, and $(\mathbf{C})$ discs sintered at $1100^{\circ} \mathrm{C}$ after day 1 of culture.

medium to decrease, indicated by the change of color from red to yellowish. SEM images (Fig. 2A) revealed that cell layers detached from the disc surface. This started at day 1 and was observed throughout the entire culture period. The number of cells present on the surface also decreased over time. At day 8, only a few viable cells were observed on the disc surface with the live and dead assay (Fig. 3A). The results of the DNA analyses (Fig. 4) confirmed the results of live and dead and SEM by showing reduced DNA content, ending close to zero at day 12. Almost no ALP activity (Fig. 5) was measured during this culture period.

\section{Preincubated Calcibon}

The results of the XRD (Fig. 1A) demonstrated that preincubation of the $\mathrm{CaP}$ cement discs in MilliQ resulted in the hydrolysis of $\alpha$-TCP into an apatite-like structure with some $\beta$-TCP. These samples caused a decrease in $\mathrm{pH}$ of the culture medium, indicated by the change of color from red to yellowish. The duration $(1,4,8$, or 12 weeks) of preincubation resulted in no changes in physico-chemical properties. Cell attachment and viability results were comparable between the preincubation periods of $1,4,8$, and 12 weeks (data not shown). SEM examination (Fig. 2B) revealed that cell layers were now only partially detaching from the disc surface and that more cells were attached to the surface than with the unmodified samples. This was already observed at day 1 but also throughout the culture period. However, live and dead assays (Fig. 3B) displayed a reduced cell number after 8 days, although the cells were well spread on the surface of the discs. DNA levels (Fig. 4) remained the same as at the start of the experiment, but ALP activity (Fig. 5) was close to zero.

\section{Sintered Calcibon}

The results of the XRD analyses (Fig. 1B) demonstrated that the discs sintered at $600^{\circ} \mathrm{C}$ had the same chemical properties as the unmodified samples. However, sintering at $800^{\circ} \mathrm{C}, 1000^{\circ} \mathrm{C}$, and $1100^{\circ} \mathrm{C}$ resulted in conversion of $\alpha$ TCP into $\beta$-TCP with some hydroxyapatite and in an increase of crystallinity (Fig. 1B). The $800^{\circ} \mathrm{C}$ samples (and to a lesser extent the $1000^{\circ} \mathrm{C}$ samples) caused a rapid increase in $\mathrm{pH}$ of the culture medium, indicated by the change of color from red to pink. The results of the live and dead and SEM analyses showed that osteoblast-like cells were not able to survive on the discs sintered at $800^{\circ} \mathrm{C}$, whereas the cells on the discs sintered at $1000^{\circ} \mathrm{C}$ were viable and proliferating. Nonetheless, the discs sintered at $1100^{\circ} \mathrm{C}$ demonstrated better cell attachment and viability throughout the culturing period of 12 days than did those sintered at the other temperatures $\left(600^{\circ} \mathrm{C}, 800^{\circ} \mathrm{C}, 1000^{\circ} \mathrm{C}\right)$ or preincubated or unmodified discs. This was confirmed using SEM examination (Fig. 2C), which showed well-spread cell layers, which were attached to the surface, and by the results of live and dead analyses (Fig. 3C) revealing the presence of live 


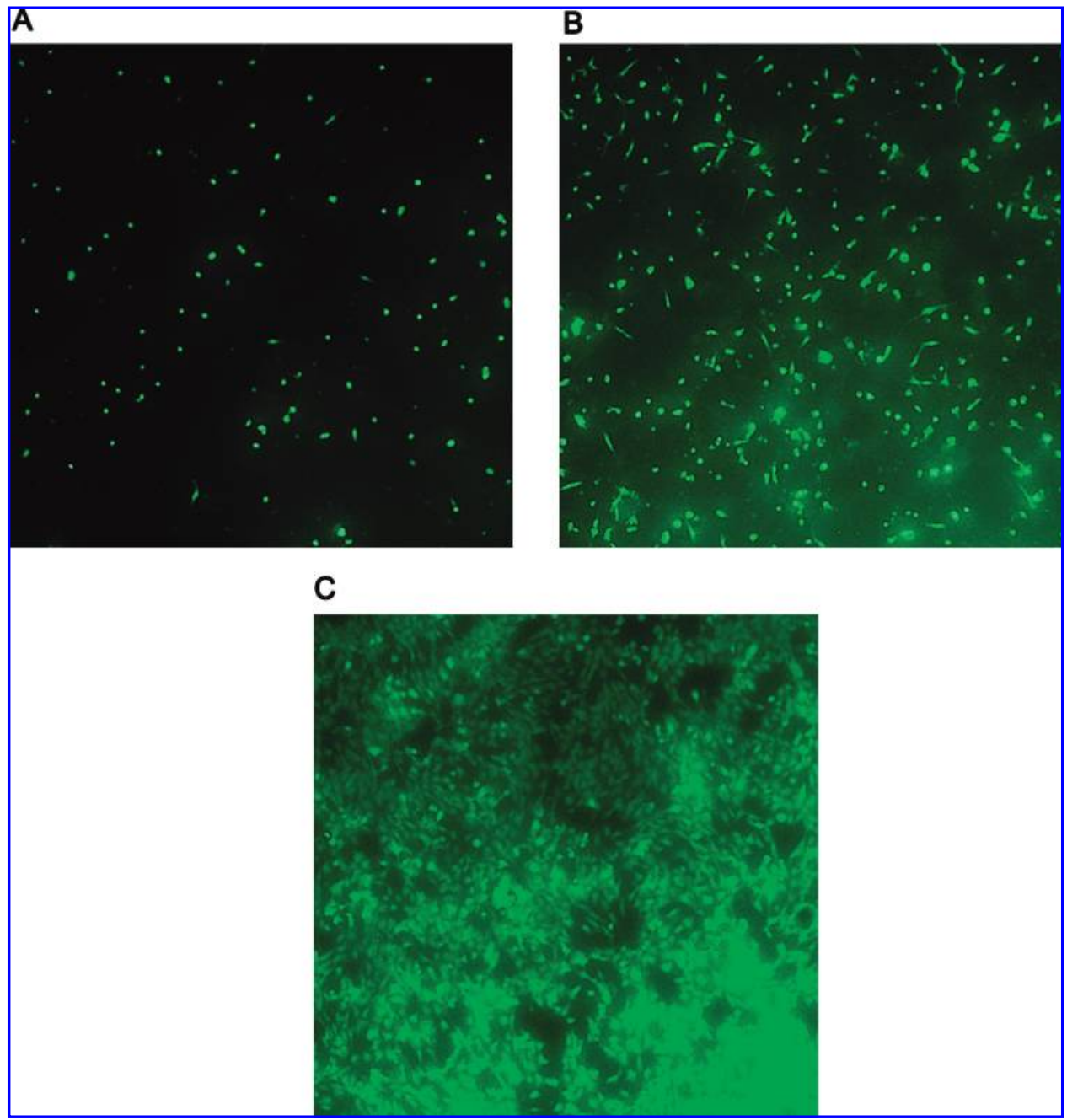

FIG. 3. Live and dead assays of (A) unmodified, (B) discs preincubated for 1 week, and (C) discs sintered at $1100^{\circ} \mathrm{C}$ after 8 days of culture. Color images available online at www.liebertpub.com/ten.

cells over the complete surface area of the discs. DNA results (Fig. 4) showed that, from day 4, the amount of DNA was significantly greater than in the preincubated and unmodified samples; the difference was even greater after 8 and 12 days. In addition, ALP activity (Fig. 5) was observed and showed a bell-shaped curve for osteoblast differentiation, with peak activity at day 8 . ALP activity at day 4 was close to the peak activity at day 8 , indicating an early differentiation of the osteoblast-like cells. The increase in ALP activity started ib the same day as cell seeding, also indicating earlier differentiation of osteoblast-like cells.

\section{DISCUSSION}

The discrepancy in results of culturing cells on Calcibon $\mathrm{CaP}$ cement was the underlying justification for the current study, with specimens receiving different additional treatments. Our results indicated that the unmodified specimens were releasing calcium and phosphate ions in the medium, creating an acidic environment for the osteoblast-like cells. As a consequence, the seeded cells were slowly dying and detached over time.

Preincubation of the CaP cement discs in MilliQ changed the chemical properties of the material. The originally present $\alpha$-TCP was hydrolyzed within 1 week of preincubation into an apatite-like structure with some $\beta$-TCP. These preincubated samples showed a little bit better cell viability than the unmodified $\mathrm{CaP}$ cement, but the material was still suppressing cell proliferation and differentiation of the osteoblast-like cells. The increase of acidity of the cell culture medium, in combination with the dissolution and re-precipitation of $\mathrm{CaP}$ phases of the discs, was hampering cell proliferation and differentiation of the osteoblast-like cells. $^{32}$

On the other hand, XRD data showed that sintering the $\mathrm{CaP}$ cement discs between $800^{\circ} \mathrm{C}$ and $1100^{\circ} \mathrm{C}$ resulted in conversion of $\alpha$-TCP to $\beta$-TCP with some hydroxyapatite and in an increase in crystallinity. The high sintering temperature in which smaller crystallites grow to larger 


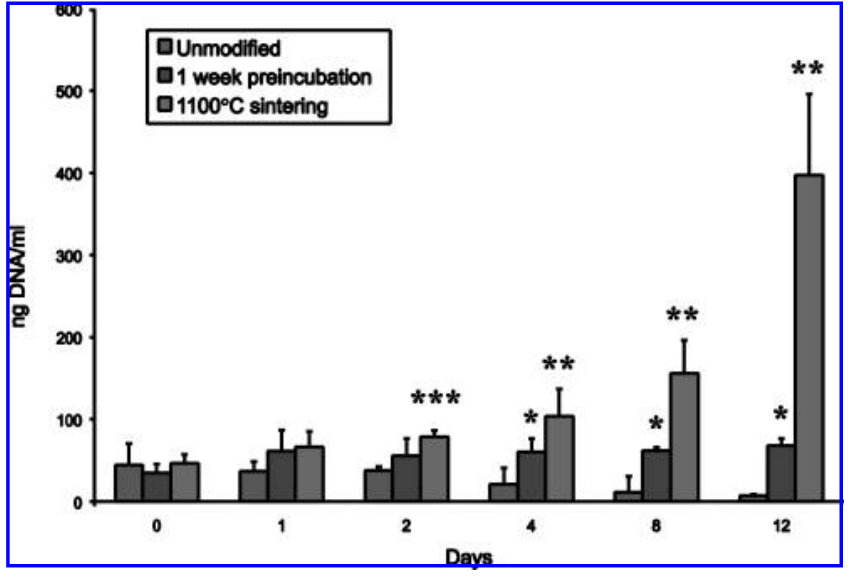

FIG. 4. Deoxyribonucleic acid (DNA) (Pico green) assay of unmodified discs, discs preincubated for 1 week, and discs sintered at $1100^{\circ} \mathrm{C}$ until 12 days of culture. ${ }^{*}$ Significant differences $(p<$ $0.05)$ between preincubated and unmodified discs; **a significant difference $(p<0.05)$ between discs sintered at $1100^{\circ} \mathrm{C}$ and preincubated and unmodified samples; $* * *$ a significant difference $(p<$ $0.05)$ between discs sintered at $1100^{\circ} \mathrm{C}$ and unmodified samples.

crystallites explains this increase in crystallinity. The discs were sintered at a maximum temperature of $1100^{\circ} \mathrm{C}$; otherwise the stable $\beta$-TCP would have been transformed into a more-reactive $\alpha$-TCP again. ${ }^{33}$ The $\beta$-TCP phase of the sintered discs favors cell proliferation and differentiation in vitro significantly, creating a good scaffold material to support osteogenesis. Remarkably, the medium of the discs sintered at $800^{\circ} \mathrm{C}$ rapidly turned basic, in which osteoblastlike cells were unable to survive. The $\mathrm{pH}$ increase was also observed in the medium of the discs sintered at $1000^{\circ} \mathrm{C}$ but to a lesser extent. Eventually, the discs sintered at $1100^{\circ} \mathrm{C}$ were the most physicochemically stable, resulting in better cellular response of osteoblast-like cells than samples sintered at other temperatures and preincubated and unmodi-

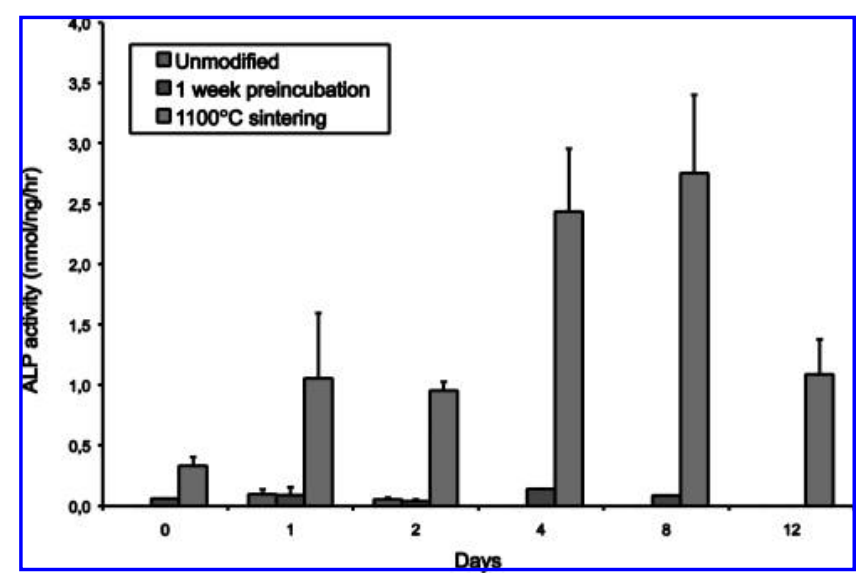

FIG. 5. Alkaline phosphatase (ALP) activity assay of unmodified discs, discs preincubated for 1 week, and discs sintered at $1100^{\circ} \mathrm{C}$ until 12 days of culture. fied samples. ${ }^{34}$ Although ALP activity on day 0 of the discs sintered at $1100^{\circ} \mathrm{C}$ was low, the discs apparently stimulated osteoblast differentiation already on the same day of cell seeding. Therefore, the elevated ALP activity in all measurements before day 8 can be explained. Furthermore, the immediate use of complete culture medium was necessary to direct the mesenchymal stem cells into the osteoblastic lineage. Previous research has indicated that the use of minimal medium during primary culture and complete medium during second culture would only delay differentiation of the osteoblast-like cells.

As mentioned before, different results have been reported regarding cell proliferation and cell differentiation of osteoblasts-like cells when cultured on Calcibon. ${ }^{28-30,35}$ For example, Hempel et al. described that the toxic effects of unmodified $\mathrm{CaP}$ cement are due to physicochemically unstable discs and released phosphate and protons into the culture medium, resulting in a decrease in $\mathrm{pH}$ and an uptake of calcium by the specimens. ${ }^{30}$ The decrease in $\mathrm{pH}$, which was reported to affect cell attachment and behavior of the osteoblast-like cells in vitro, was also observed in our experiments with the unmodified and preincubated samples. ${ }^{36-38}$ Its changed color, which went from red to yellowish, illustrated the alteration of the $\mathrm{pH}$ in the culture medium. This effect is the consequence of the presence of $\mathrm{pH}$ indicators in the $\alpha$-MEM solution. In contrast to Hempel et al., Oreffo et $a l$. and Knabe et al. reported lower cell proliferation and greater cell differentiation on Calcibon than with polystyrene cultures, although they were still able to culture the cells for an extended period. ${ }^{28,29}$ Our results showed fewer cells on unmodified specimens over time. The alteration in $\mathrm{pH}$ and extracellular concentrations of calcium and phosphate were found to cause considerable stress for the osteoblast-like cells and ultimately resulted in severely limited cell growth and differentiation. ${ }^{30}$ It was reported that this could be avoided by refreshing the medium daily, instead of every 2 to 3 days. In this way, cell viability can be maintained and cell proliferation and differentiation of the osteoblast-like cells improved. ${ }^{39}$ In addition to the decrease in $\mathrm{pH}$ and the uptake of calcium by the specimens, the negative effects on osteoblastlike cells could be due to the particle size of the $\mathrm{CaP}$ cement. Pioletti et al. described that $\mathrm{CaP}$ cement particles smaller than $10 \mu \mathrm{m}$ have an effect on the viability and proliferation of osteoblast-like cells. ${ }^{40}$

Evidently, the observed acidity of Calcibon $\mathrm{CaP}$ cement in in vitro cell culture experiments does not hamper the final in vivo behavior of the material, because in vivo studies with Calcibon $^{21,24,41}$ describe excellent bone compatibility, as characterized by the fast deposition of new bone on the cement surface, which proves that the material is osteoconductive and suitable for clinical purposes. A reason for the excellent in vivo behavior might be vascularization, which provides a continuous flow around the inserted implant that can elute the toxicity of the $\mathrm{CaP}$ cement. This emphasizes that in vitro cell studies cannot be extrapolated implicitly to the in vivo situation, which Rosengren et al., who found that 
an initially cytotoxic scaffold in vitro could, over the long term, become biocompatible in vivo, described. ${ }^{42}$

\section{CONCLUSIONS}

On basis of our results, we conclude that in vivo results with CaP-based cements do not guarantee their in vitro applicability. Furthermore, unmodified Calcibon is not cytocompatible in vitro; although preincubation of the material results in a more-favorable cell response, sintering of the material at $1100^{\circ} \mathrm{C}$ resulted in the best osteogenic properties. In contrast to in vivo studies, the Calcibon $\mathrm{CaP}$ cement is not suitable as a scaffold for cell-based tissue-engineering strategies.

\section{ACKNOWLEDGMENTS}

We would like to thank the Dutch Technology Foundation (STW) applied science division of NWO and the technology program of the Ministry of Economic Affairs for their financial support in this project (NGT6205).

\section{REFERENCES}

1. Mastrogiacomo M, Muraglia A, Komlev V, Peyrin F, Rustichelli F, Crovace A, Cancedda R. Tissue engineering of bone:search for a better scaffold. Orthod Craniofac Res 2005;8:277-84.

2. Ohgushi H, Goldberg V.M., Caplan A.I. Repair of bone defects with marrow cells and porous ceramic. Experiments in rats. Acta Orthop Scand 1989;60:334-9.

3. Goshima J, Goldberg V.M., Caplan A.I. The osteogenic potential of culture-expanded rat marrow mesenchymal cells assayed in vivo in calcium phosphate ceramic blocks. $\underline{\text { Clin }}$ Orthop Relat Res 1991;298-311.

4. Bruder S.P., Jaiswal N, Ricalton N.S., Mosca J.D., Kraus K.H., Kadiyala S. Mesenchymal stem cells in osteobiology and applied bone regeneration. Clin Orthop Relat Res 1998;S247-56.

5. Bruder S.P., Kraus K.H., Goldberg V.M., Kadiyala S. The effect of implants loaded with autologous mesenchymal stem cells on the healing of canine segmental bone defects. $\mathrm{J}$ Bone Joint Surg Am 1998;80:985-96.

6. Bruder S.P., Kurth A.A., Shea M, Hayes W.C., Jaiswal N, Kadiyala S. Bone regeneration by implantation of purified, culture-expanded human mesenchymal stem cells. J Orthop Res 1998;16:155-62.

7. Kon E, Muraglia A, Corsi A, Bianco P, Marcacci M, Martin I, Boyde A, Ruspantini I, Chistolini P, Rocca M, Giardino R, Cancedda R, Quarto R. Autologous bone marrow stromal cells loaded onto porous hydroxyapatite ceramic accelerate bone repair in critical-size defects of sheep long bones. Mater Res 2000;49:328-37.

8. Bruder S.P., Fink D.J., Caplan A.I. Mesenchymal stem cells in bone development, bone repair, and skeletal regeneration therapy. J Cell Biochem 1994;56:283-94.
9. Fickert S, Fiedler J, Brenner R.E. Identification, quantification and isolation of mesenchymal progenitor cells from osteoarthritic synovium by fluorescence automated cell sorting. Osteoarthritis Cartilage 2003;11:790-800.

10. Gronthos S, Zannettino A.C., Hay S.J., Shi S, Graves S.E., Kortesidis A, Simmons P.J. Molecular and cellular characterisation of highly purified stromal stem cells derived from human bone marrow. J Cell Sci 2003;116:1827-35.

11. Jones E.A., Kinsey S.E., English A, Jones R.A., Straszynski L, Meredith D.M., Markham A.F., Jack A, Emery P, McGonagle D. Isolation and characterization of bone marrow multipotential mesenchymal progenitor cells. Arthritis Rheum 2002; 46:3349-60.

12. van den Dolder J, Bancroft G.N., Sikavitsas V.I., Spauwen P.H., Jansen J.A., Mikos A.G. Flow perfusion culture of marrow stromal osteoblasts in titanium fiber mesh. J Biomed Mater Res 2003;64A:235-41.

13. Zhao F, Ma T. Perfusion bioreactor system for human mesenchymal stem cell tissue engineering: dynamic cell seeding and construct development. Biotechnol Bioeng 2005;91:482-93.

14. Tanaka S.M., Sun H.B., Roeder R.K., Burr D.B., Turner C.H., Yokota H. Osteoblast responses one hour after load-induced fluid flow in a three-dimensional porous matrix. Calcif Tissue Int 2005;76:261-71.

15. $\overline{\mathrm{Yu}}$ X, Botchwey E.A., Levine E.M., Pollack S.R., Laurencin C.T. Bioreactor-based bone tissue engineering: the influence of dynamic flow on osteoblast phenotypic expression and matrix mineralization. Proc Natl Acad Sci U S A 2004;101:11203-8.

16. Cartmell S.H., Porter B.D., Garcia A.J., Guldberg R.E. Effects of medium perfusion rate on cell-seeded three-dimensional bone constructs in vitro. Tissue Eng 2003;9:1197-203.

17. Payne R.G., Yaszemski M.J., Yasko A.W., Mikos A.G. Development of an injectable, in situ crosslinkable, degradable polymeric carrier for osteogenic cell populations. Part 1. Encapsulation of marrow stromal osteoblasts in surface crosslinked gelatin microparticles. Biomaterials 2002;23:4359-71.

18. Koch S, Schwinger C, Kressler J, Heinzen Ch., Rainov N.G. Alginate encapsulation of genetically engineered mammalian cells: comparison of production devices, methods and microcapsule characteristics. J Microencapsul 2003;20:303-16.

19. Liu Z.C., Chang T.M. Increased viability of transplanted hepatocytes when hepatocytes are co-encapsulated with bone marrow stem cells using a novel method. Artif Cells Blood Substit Immobil Biotechnol 2002;30:99-112.

20. Tobias C.A., Han S.S., Shumsky J.S., Kim D, Tumolo M, Dhoot N.O., Wheatley MA, Fischer I, Tessler A, Murray M. Alginate encapsulated BDNF-producing fibroblast grafts permit recovery of function after spinal cord injury in the absence of immune suppression. J Neurotrauma 2005;22:138-56.

21. del Real R.P., Ooms E, Wolke J.G., Vallet-Regi M, Jansen J.A. In vivo bone response to porous calcium phosphate cement. J Biomed Mater Res 2003;65A:30-6.

22. Ruhe P.Q., Hedberg-Dirk E.L., Padron N.T., Spauwen P.H., Jansen J.A., Mikos A.G. Porous poly(DL-lactic-co-glycolic acid)/calcium phosphate cement composite for reconstruction of bone defects. Tissue Eng 2006;12:789-800.

23. Ruhe P.Q., Hedberg E.L., Padron N.T., Spauwen P.H., Jansen J.A., Mikos A.G. rhBMP-2 release from injectable poly(DLlactic-co-glycolic acid)/calcium-phosphate cement composites. J Bone Joint Surg Am 2003;85-A Suppl 3:75-81. 
24. Ooms E.M., Wolke J.G., van der Waerden J.P., Jansen J.A. Trabecular bone response to injectable calcium phosphate (Ca-P) cement. J Biomed Mater Res 2002;61:9-18.

25. Ooms E.M., Egglezos E.A., Wolke J.G., Jansen J.A. Soft-tissue response to injectable calcium phosphate cements. Biomaterials 2003;24:749-57.

26. del Real R.P., Wolke J.G., Vallet-Regi M, Jansen J.A. A new method to produce macropores in calcium phosphate cements. Biomaterials 2002;23:3673-80.

27. Ruhe P.Q., Hedberg E.L., Padron N.T., Spauwen P.H., Jansen J.A., Mikos A.G. Biocompatibility and degradation of poly(DLlactic-co-glycolic acid)/calcium phosphate cement composites. J Biomed Mater Res A 2005;74:533-44.

28. Oreffo R.O., Driessens F.C., Planell J.A., Triffitt J.T. Growth and differentiation of human bone marrow osteoprogenitors on novel calcium phosphate cements. Biomaterials 1998;19: 1845-54.

29. Knabe C, Berger G, Gildenhaar R, Meyer J, Howlett C.R., Markovic B, Zreiqat H. Effect of rapidly resorbable calcium phosphates and a calcium phosphate bone cement on the expression of bone-related genes and proteins in vitro. Mater Res A 2004;69:145-54.

30. Hempel U, Reinstorf A, Poppe M, Fischer U, Gelinsky M, Pompe W, Wenzel KW. Proliferation and differentiation of osteoblasts on Biocement D modified with collagen type I and citric acid. J Biomed Mater Res 2004;71B:130-43.

31. Maniatopoulos C, Sodek J, Melcher A.H. Bone formation in vitro by stromal cells obtained from bone marrow of young adult rats. Cell Tissue Res 1988;254:317-30.

32. John A, Varma H.K., Kumari T.V. Surface reactivity of calcium phosphate based ceramics in a cell culture system. J Biomater Appl 2003;18:63-78.

33. Langstaff S, Sayer M, Smith T.J., Pugh S.M., Hesp S.A., Thompson W.T. Resorbable bioceramics based on stabilized calcium phosphates. Part I: rational design, sample preparation and material characterization. Biomaterials 1999;20: 1727-41.

34. Reid J.W., Pietak A, Sayer M, Dunfield D, Smith T.J. Phase formation and evolution in the silicon substituted tricalcium phosphate/apatite system. Biomaterials 2005;26:2887-97.
35. Knepper-Nicolai B, Reinstorf A, Hofinger I, Flade K, Wenz $\mathrm{R}$, Pompe W. Influence of osteocalcin and collagen I on the mechanical and biological properties of Biocement D. Biomol Eng 2002;19:227-31.

36. Sharpe J.R., Sammons R.L., Marquis P.M. Effect of $\mathrm{pH}$ on protein adsorption to hydroxyapatite and tricalcium phosphate ceramics. Biomaterials 1997;18:471-6.

37. Kaysinger K.K., Ramp W.K. Extracellular pH modulates the activity of cultured human osteoblasts. J Cell Biochem 1998;68:83-9.

38. Krieger N.S., Frick K.K., Bushinsky D.A. Mechanism of acid-induced bone resorption. Curr Opin Nephrol Hypertens 2004;13:423-36.

39. Knabe C, Gildenhaar R, Berger G, Ostapowicz W, Fitzner R, Radlanski R.J., Gross U. Morphological evaluation of osteoblasts cultured on different calcium phosphate ceramics. Biomaterials 1997;18:1339-47.

40. Pioletti D.P., Takei H, Lin T, Van Landuyt P, Ma Q.J., Kwon S.Y., Sung K.L. The effects of calcium phosphate cement particles on osteoblast functions. Biomaterials 2000;21: 1103-14.

41. Comuzzi L, Ooms E, Jansen J.A. Injectable calcium phosphate cement as a filler for bone defects around oral implants:an experimental study in goats. Clin Oral Implants Res 2002;13:304-11.

42. Rosengren A, Faxius L, Tanaka N, Watanabe M, Bjursten L.M. Comparison of implantation and cytotoxicity testing for initially toxic biomaterials. J Biomed Mater Res A 2005;75: $115-22$.

Address reprint requests to: John A. Jansen, D.D.S., Ph.D. Department of Periodontology and Biomaterials Radboud University Nijmegen Medical Center PO Box 9101 6500 HB Nijmegen The Netherlands

E-mail: J.Jansen@dent.umcn.nl 
This article has been cited by:

1. Dennis P. Link, Juliette van den Dolder, Jeroen J. J. P. van den Beucken, Vincent M. Cuijpers, Joop G. C. Wolke, Antonios G. Mikos, John A. Jansen. 2009. Evaluation of the biocompatibility of calcium phosphate cement/PLGA microparticle composites. Journal of Biomedical Materials Research Part A 87A:3, 760-769. [CrossRef]

2. Elisabeth Engel, Sergio Del Valle, Conrado Aparicio, George Altankov, Luis Asin, Josep A. Planell, Maria-Pau Ginebra . 2008. Discerning the Role of Topography and Ion Exchange in Cell Response of Bioactive Tissue Engineering ScaffoldsDiscerning the Role of Topography and Ion Exchange in Cell Response of Bioactive Tissue Engineering Scaffolds. Tissue Engineering Part A 14:8, 1341-1351. [Abstract] [PDF] [PDF Plus]

3. Sergey V. Dorozhkin. 2008. Calcium orthophosphate cements for biomedical application. Journal of Materials Science 43:9, 3028-3057. [CrossRef] 